\title{
The Developing Concept of Tonotopic Organization of the Inner Ear
}

\author{
ROBERT J. RUBen ${ }^{1}$ (1) \\ ${ }^{1}$ Departments of Otorhinolaryngology - Head and Neck Surgery and Pediatrics, Albert Einstein College of Medicine, Montefiore \\ Medical Center, New York, NY, USA
}

Received: 16 April 2019; Accepted: 30 December 2019; Online publication: 4 February 2020

\begin{abstract}
This study aims to document the historical conceptualization of the inner ear as the anatomical location for the appreciation of sound at a continuum of frequencies and to examine the evolution of concepts of tonotopic organization to our current understanding. Primary sources used are from the sixth century BCE through the twentieth century CE. Each work/reference was analyzed from two points of view: to understand the conception of hearing and the role of the inner ear and to define the main evidential method. The dependence on theory alone in the ancient world led to inaccurate conceptualization of the mechanism of hearing. In the sixteenth century, Galileo described the physical and mathematical basis of resonance. The first theory of tonotopic organization, advanced in the seventeenth century, was that high-frequency sound is mediated at the apex of the cochlea and low-frequency at the base of the cochlea. In the eighteenth and nineteenth centuries, more accurate anatomical information was developed which led to what we now know is the accurate view of tonotopic organization: the high-frequency sound is mediated at the base and low-frequency sound at the apex. The electrical responses of the ear discovered in 1930 allowed for physiological studies that were consistent with the concept of a high to low tone sensitivity continuum from base to apex. In the mid-twentieth century, physical observations of models and anatomical specimens confirmed the findings of greater sensitivity to high tones at the base and low tones at the apex and, further, demonstrated that for high-intensity sound, there was a spread of effect through the entire cochlea,

Correspondence to: Robert J. Ruben · Departments of Otorhinolaryngology - Head and Neck Surgery and Pediatrics, Albert Einstein College of Medicine - Montefiore Medical Center · New York, NY, USA. email: rruben@montefiroe.org
\end{abstract}

more so for low-frequency tones than for high tones. Animal and human behavioral studies provided empirical proof that sound is mediated at a continuum of frequencies from high tones at the base through low tones at the apex of the cochlea. Current understanding of the tonotopic organization of the inner ear with regard to pure tones is the result of the acquisition over time of knowledge of acoustics and the anatomy, physical properties, and physiology of the inner ear, with the ultimate verification being behavioral studies. Examination of this complex evolution leads to understanding of the way each approach and evidential method through time draws upon previously developed knowledge, with behavioral studies providing empirical verification.

Keywords: hearing, tonotopic organization, cochlea, acoustics, anatomy, physiology, psychophysics

\section{INTRODUCTION}

The earliest written records concerning how we hear are to be found in the classical Greek and Roman literature. The unfolding of this knowledge continuing into the twenty-first century, with a particular inquiry into the narrative of understanding of the localization of hearing, is the focus of this study.

How we hear has been and continues to be a concern to musicians, scientists of many types, and physicians. Throughout time, our understanding has undergone revisions dependent upon the development of many forms of knowledge including music, acoustics, physiology, anatomy, psychophysics, and medicine. There is a hierarchy of validity of each of the various evidential methods used to achieve each 
advance. This report ranks these methods, with the theoretical-only explanations, that is, those originating from the fifth century BCE to the sixteenth century, having the least validity. The period from the sixteenth century to the nineteenth century is marked by increasing validity for observation of anatomical structure that could account for localization of sound perception. The period from the nineteenth century into the twentieth century sees advances in validity through physical models utilizing simulation, followed by physical models utilizing biological material. In the twentieth century and into the twenty-first century, physiological observations and animal and human behavioral studies increased the validity of understanding the process by which we hear.

\section{THE CLASSICAL WORLD OF GREECE AND ROME (500 BCE-200 CE)}

The classical theory of hearing, in general, was that the mind had only a passive role as it received direct impressions from the outside world and that objects were perceived as they truly existed. In this period of theoretical-only explanations, these concepts were not based on human dissection.

The philosopher/mathematician Pythagoras (ca. 570 BCE-495 BCE) and his school, while not involved in investigating hearing, are significant in the history of ideas about tonotopic organization of hearing because they provided the beginning for the concept of pure tones. They studied how pure tones were physically generated by determining that plucking a string produced a tone related to the length of the string, as well as that harmony was a mathematical proportion, and they developed the mathematics that could begin to explain these phenomena (Robinson 1941; Sigerist 1961). These data would become the foundation for the concept of tonotopic organization of the cochlea.

What is remarkable about the early concept of hearing of the philosopher Alcmaeon (Sigerist 1961), probably of the first half of the fifth century BCE, is his evident insight into the role of the brain in perception. He writes:

Hearing arises when an external sound is first transmitted to the outer ear and then picked up by the empty space (kenon) in the inner ear, which transmits it to the brain... (Alcmaeon 2018)

Alcmaeon appears to be the first to recognize the brain as the seat for sensory perception as well as for memory and thought. In this he was far more accurate than Aristotle who lived a century later and who was far more influential for subsequent scientific thought.
Two competing and subsequently influential views of the process of hearing arose in the later part of the fifth century BC, Hippocrates' "echo" concept and Empedocles' idea of "inner air". The view of the physician Hippocrates (ca. 460 BCE-370 BCE) can be related to the classical Greek concept that perception mirrors the external world-that "like is perceived by like" (Finger 1994; Wever 1949; Werner 1932). This was an echo theory. In the Hippocratic texts, the hearing apparatus consists of an external auditory canal ending in a spider web-like dry membrane which leads to a hard, dry, and stony bone. The sound discovers the bone and creates an echo: the stronger the echo, the louder the sound.

The "air" theory of hearing first appears in the fragments of the writings of Hippocrates' older contemporary, the philosopher Empedocles (Sigerist 1961) (ca. 494 434 BCE). He deduced that there is "internal air" through which moving air is perceived, and this perception leads to hearing. The air in the tympanic cavity was considered as the essential substance by which aerial vibration is perceived. The tympanic air was thought to be a highly refined substance and was a permanent part of the sense organ (Wever 1949; Werner 1932).

Empedocles described his concept of hearing as follows:

And hearing is the result of noise coming from outside. For when (the air) is set in motion by a sound, there is an echo within; for the hearing is as it were a bell echoing within, and the ear he calls an 'offshoot of flesh: and the air when it is set in motion strikes on something hard and makes an echo. Hearing takes place by the impact of wind on the cartilage of the ear, which, he says, is hung up inside the ear so as to swing and be struck after the manner of a bell. (Empedocles 2010)

The philosopher Plato (424/423 BCE-348/ 347 BCE), in his dialog Timaeus (Plato 2017), has a character theorize about hearing and the function of air within the ear as follows:

... Hearing is the effect of a stroke which is transmitted through the ears by means of the air, brain, and blood to the soul, beginning at the head and extending to the liver. The sound which moves swiftly is acute; that which moves slowly is grave; that which is uniform is smooth, and the opposite is harsh. Loudness depends on the quantity of the sound ...

the ear is the aperture through which the vibrations of sound pass. But that the complex structure of the eye or the ear is in any sense the cause of 
sight and hearing he seems hardly to be aware. The swifter sound is acute; the sound which moves slowly is grave. A great body of sound is loud, the opposite is low. Discord is produced by the swifter and slower motions of two sounds, and is converted into harmony when the swifter motions begin to pause and are overtaken by the slower ... (Plato 2017)

Following earlier ideas, the philosopher Aristotle (384-322 BCE) stated that a sound is perceived by the ear because there is air in the ear that vibrates with the air outside of the ear. If the air in the ear, middle ear cleft, is lost, then there is no hearing, i.e., deafness:

The organ of hearing is physically united with air, and because it is in air, the air inside is moved concurrently with the air outside. Hence animals do not hear with all parts of their bodies, nor do all parts admit of the entrance of air; for even the part which can be moved and can sound has not air everywhere in it. Air in itself is, owing to its friability, quite soundless; only when its dissipation is prevented is its movement sound. The air in the ear is built into a chamber just to prevent this dissipating movement, in order that the animal may accurately apprehend all varieties of the movements of the air outside. That is why we hear also in water, viz. because the water cannot get into the air chamber or even, owing to the spirals, into the outer ear. If this does happen, hearing ceases, as it also does if the tympanic membrane is damaged, just as sight ceases if the membrane covering the pupil is damaged. It is also a test of deafness whether the ear does or does not reverberate like a horn; the air inside the ear has always a movement of its own, but the sound we hear is always the sounding of something else, not of the organ itself. That is why we say that we hear with what is empty and echoes, viz. because what we hear with is a chamber which contains a bounded mass of air. (Aristotle 2010)

Texts of Hippocrates and Aristotle continued to be used by physicians, including those concerned with hearing, to the Renaissance. The anatomical concept of the air in the ear, "aer internus," largely through the dominance of Aristotelianism, was the basis of the understanding of ear physiology until the middle of the eighteenth century (Békésy and Rosenblith 1948; Cotugno 1760).

All of these concepts had the least validity in the historical development of understanding hearing because all were products of theory alone and did not develop through the observation of dissections. Perhaps the earliest theory based on the observations of anatomical structure was that of Galen (130 BCE$200 \mathrm{CE}$ ) who dissected the ear of various animals including pigs and primates (Ajita 2015). He observed the inner ear and wrote about the way the inner ear protects from sound trauma the nerve he also observed that leads into the inner ear (Galen 1968; Siegel 1970):

Accordingly, she [Mother Nature] added a dense, hard bone and bored through it with oblique coils like a labyrinth, being careful gradually to dull, by intricate deflections, the direct force which the cold air would have if the pathway were straight, and to check the impact of all other, hard bodies. (Galen 1968)

Galen's theory of hearing was based upon the anatomical structure of the labyrinth, which he named (Galen 1968). The labyrinth served as a tortuous channel to protect the nerve endings from damage by very strong sound. He brought the ideas of Hippocrates, Empedocles, and Aristotle to his understanding of hearing, utilizing the concepts of inner air and transmission of a mirror image to the brain by the nerves.

\section{SIXTEENTH CENTURY}

To our knowledge, the first complete and separate tome on the ear is by Volcher Cöiter (1534-1576), De auditus instrumento in 1566 (Coïter 1572), which included a section on the transmission of sound. Cöiter was an anatomist in Bologna noted for his studies of osteology and meningitis and for obtaining permission to perform autopsies to understand disease (Castiglioni 1941). The source for the date is Ernst Glen Wever (Wever 1949) who states that this text first appeared separately in 1566 as a part of Cöiter, Volcher (1534-1576), Externarum et internarum principalium humani corporis partium tabulae, Nuremberg: Dietrich Gerlach, 1573. See https:// archive.org/details/hin-wel-all-00000250-001 and the Vatican Library; the author has not been able to locate a copy of that publication, and the earliest located is 1572 . Cöiter traces the vibrations from the entrance of the external auditory meatus through the middle ear and via the cochlea and labyrinth to the auditory nerve. He appears to be the first investigator on record who opposed the idea of implanted air in the tympanic cavity although his idea was not immediately taken up. Cöiter reasoned that the distinctive properties of the inner air could not be preserved 
since there was an opening to the throat, and therefore, the surrounding air could replace whatever was in the cavity.

\section{SEVENTEENTH CENTURY}

Casper Bauhin (1560-1624) of Basel appears to be the first to hypothesize a resonance theory of hearing in his Theatrum Anatomicum infinitis locis auctum written in 1592 and first published in 1605 (Bauhin 1605) (Fig. 1). This was formulated before there was detailed knowledge of the inner ear and the concept of enclosed air was still the accepted mechanism for hearing. He stated that when aerial waves beat upon the ear, there is resonance in its various tubes and spaces, in the depths of which the auditory nerve lies. The resonance is selective for the cavities contain openings of different sizes, lengths, and forms. He still thought that most of the transduction occurred in the middle ear but allowed for possible processing in the inner ear.

Perhaps a lesser known but critical scientific achievement of Galileo Galilei (1564-1642) is his study of the mathematical basis of resonance which demonstrates that the shorter a string in a musical instrument or other sound-making device, the higher the resonant frequency and vice versa. Galileo brings the Pythagorean concept, with which he was familiar, to a more complete mathematical description. Galileo's formulation underlies our current understanding of the tonotopic organization of the cochlea. Galileo in 1638 published his studies of the mathematical basis of resonance in Discorsi e dimostrazioni matematiche intorno à due nuoue scienze attenenti alla mecanica $\mathcal{E} i$ mouimenti locali ... Con vna appendice del

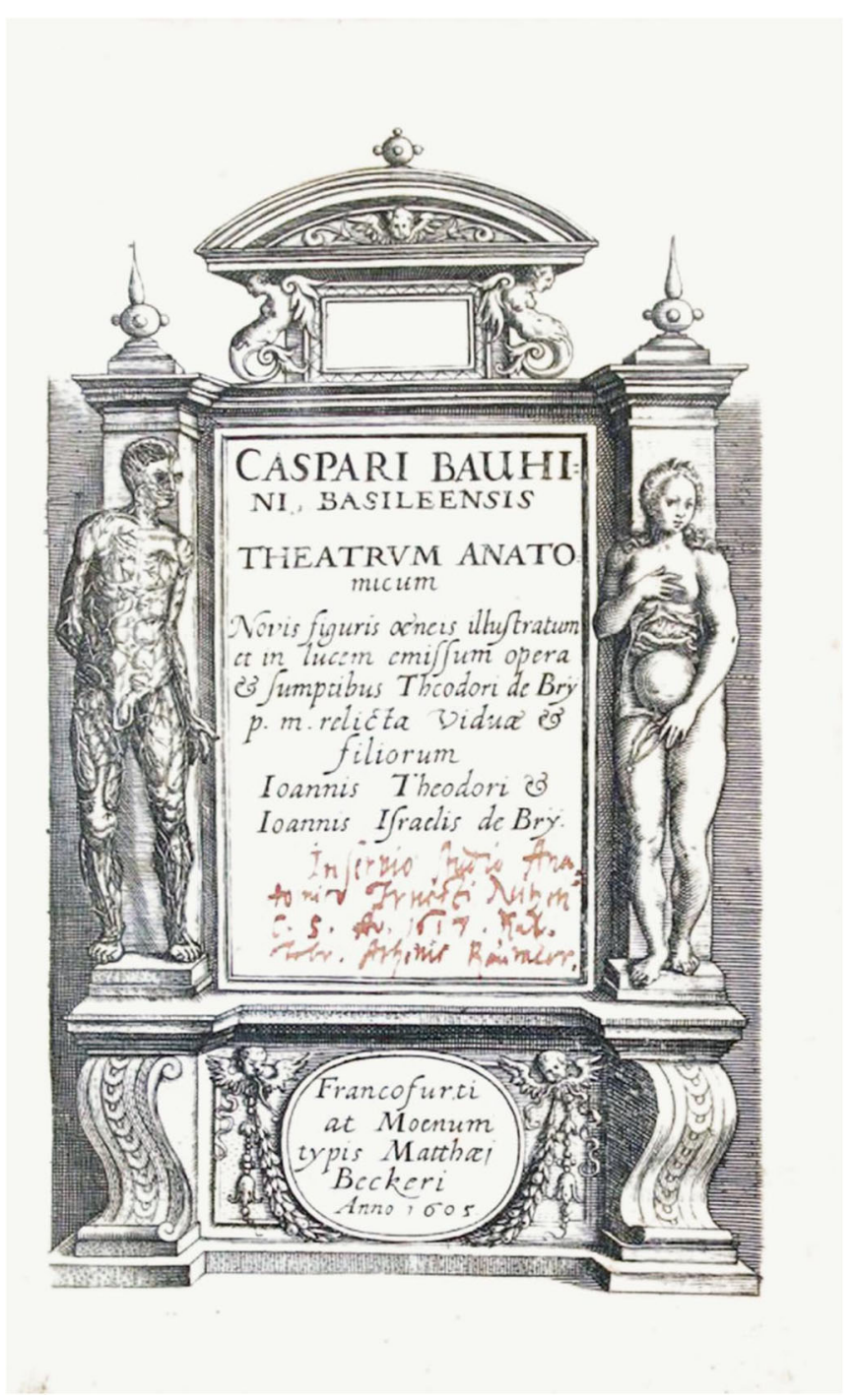

FIG. 1. Theatrum anatomicum infinitis locis auctum written in 1592 and first published in 1605. Bauhin (1605), frontispiece. Courtesy of the Library of the New York Academy of Medicine, Arlene Shaner 
centro di grauità d'alcuni solidi (Gallie 1914; Galilei 1638). First, he described the acoustical and visual effects of resonance using church bells, stringed instruments, and a glass of water as his examples. He then quantified the effects on a string to produce a sound by stretching, shortening, or making it thinner. These data were then expressed as mathematical formulations which he illustrates in his Figure 13 (Galilei 1638) (Fig. 2).

Galileo's explanation of the illustration in Fig. 2 includes this clarification:

Let $\mathrm{AB}$ denote the length of a wave emitted by the lower string and $\mathrm{CD}$ that of a higher string which is emitting the octave of $\mathrm{AB}$; divide $\mathrm{AB}$ in the middle at $\mathrm{E}$. If the two strings begin their motions at $\mathrm{A}$ and $\mathrm{C}$, it is clear that when the sharp vibration has reached the end $\mathrm{D}$, the other vibration will have travelled only as far as E, which, not being a terminal point, will emit no pulse; but there is a blow delivered at $\mathrm{D}$. Accordingly when the one wave comes back from $\mathrm{D}$ to $\mathrm{C}$, the other passes on from $\mathrm{E}$ to $\mathrm{B}$; hence the two pulses from $\mathrm{B}$ and $\mathrm{C}$ strike the drum of the ear simultaneously. Seeing that these vibrations are repeated again and again in the same manner, we conclude that each alternate pulse from $\mathrm{CD}$ falls in unison with one from $\mathrm{AB}$. But each of the $\mathrm{C} D$ pulsations at the terminal points, $\mathrm{A}$ and $\mathrm{B}$, is constantly accompanied by one which leaves always from $\mathrm{C}$ or always from D. (Gallie 1914)

Anatomical knowledge of the inner ear increased during the latter part of the seventeenth century. Thomas Willis (1621-1675) in his De anima brutorum of

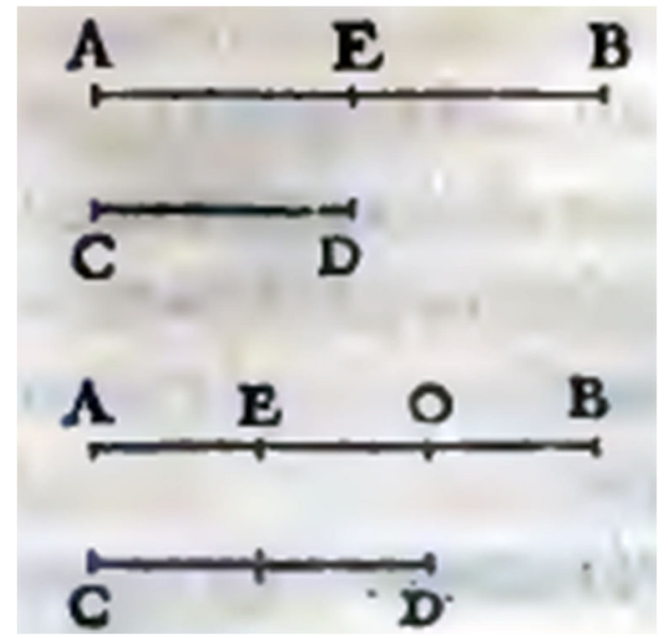

Fig. 2. Galileo Galilei's (1564-1642) 1638 illustration of the mathematical basis of resonance. The original in Galileo's text measures $2.5 \times 2.5 \mathrm{~cm}$ and is enlarged for this publication. Galilei (1638), figure 13, page 104. Courtesy of Biblioteca Apostolica Vaticana, photograph by the author
1672 (Willis 1672) identifies the function of the labyrinth as the organ of hearing:

But from the aforesaid Den, place behind the Drum, another passage leads towards that part, which is properly the Organ of Hearing; to wit, in the extreme side of that Cavern, before mentioned, there is a door, or certain round hole, covered with a thin Membrane, commonly called the Window, and beyond that whole, to wit in the end or shop process of the stony Bone, is the Shell, contain: from whence we may think very sharp processes of the stony Bone, is the Shell contain: from whence we may think very well, that the impression of the sound brought through its next Chamber from the Drum, is that's propagated, by an impulse made above the Window, into the shell. (Willis and Pordage 1683)

Willis also affirmed the earlier observation of Cöiter of the impossibility of implanted embryonic air (Plato 2017; Aristotle 2010 in the middle ear-i.e., the cave/den-because the middle ear was connected to the pharynx, resulting in the exchange of air in the middle ear:

Behind the Drum, the Den or Cavity subsists, in which the Ancients placed the implanted Air, which received the impressed sound from the Drum: which thing indeed is not unlikely; for, because the waiving of the sound ought to be conveyed still further towards the Sensory, it seems that the Sonorifick Particles, which are their Vehicle, are contained within this Den; and because it is needful, that Sonorific [k] Particles, included in this Den, should be in some measure consumed; therefore from this hidden place, there lies an open passage into the Palate; but yet after that manner, that little doors being placed in its upper part, it admits the Air fetched from the Palate, as often as there is need; but the same being admitted into the Den of the Ear, its passage out by the same way is hindered. (Willis and Pordage 1683)

During the reign of Louis XIV, a major undertaking of anatomy was carried out in Paris and Versailles through animal and human dissection (Guerrini 2015). In this context, work on the inner ear and theory of hearing are detailed in two works. The first of these, by Charles Perrault (1628-1703), is incorporated as Chapter II, "Du Bruit," in Perrault's Essais De Physique, Ou Recueil De Plusieurs Traitez touchant les choses naturelles of 1680 (Du Bruit 1680) (Fig. 3).

Perrault recognized the spiral nature of the cochlea, as had been earlier noted by Cöiter (Coïter 1572) (Galen had described the spiral nature of the cochlea, but this was unknown to Perrault since the Galen 


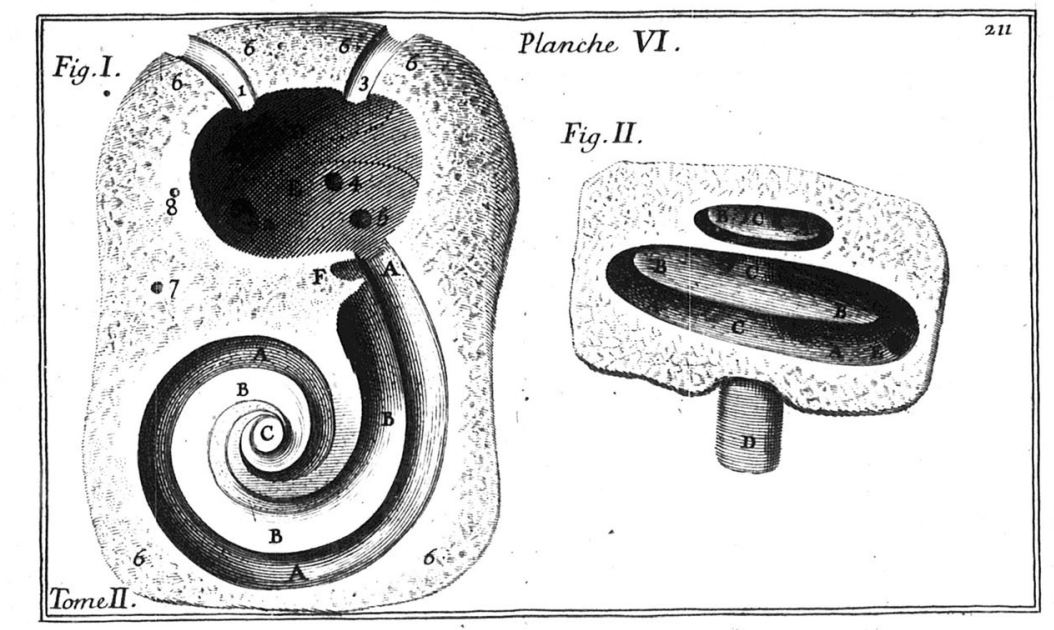

EXPIICATION DE LA PIANCHE VI.

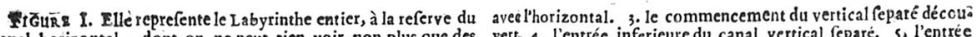
canal horizontal, dont on ne peut rien voir non plus que des vert. 4. l'entrée inferieure du canal vertical feparé. So l'entrée parties fuperieures qu'il a fallu enlever pour faire voir le dedans, il particuliere du. canal horrzonta.
a une grandeur beaucoup au delà du naturel. AA.le Canal fpiral appellé le Limą̧on. B BB, la Membrane f́pira- perpendiculairement au plan marqué $6,5,6,6$. dans la 1 . Figure. 1e. DE, le Veftibule du Labyrinthe découvert, de mefme que le A A A. le dedans du canal fpiral qui fait le Limaçon. B B B. Ia commencement des canaux verticaux \& du Limaçon, par une fe- membrane fpirale. C C C. le noyau auquel la membrane eft atetion qui forme le plan marque 6,6,6,6. I. Ie commencement du tachec. D. le nerf de l'ouic qui paffe dans lé noyau \& le penetre.

FIG. 3. Perrault's illustration in which he recognized the spiral nature of the cochlea (Perrault 1680). Courtesy of the Fordham University Library, photograph by the author

manuscript only came to light in the twentieth century (Galen 1968)). Perrault assumed that the implanted air was in the spiral passages of the cochlea and theorized that this anatomy allows for the spread of vibratory movements over a greater area of nervous substance and thus would gain sensitivity. Perrault's findings appear to be the earliest observation of the function of the anatomical structure, the spiral cochlea, which could account for localization of sound perception. He was the first to relate the physical structure with the way in which sound is perceived.

Guichard Joseph Du Verney (1648-1730), a colleague of Perrault, was the first to develop a tonotopic theory of hearing based on anatomical structure. His only book (Du Verney 1683) (Fig. 4) was written in the vernacular French, not in the traditional Latin. It was translated from 1684 until 1750 into Latin, German, Dutch, and English (Asherson 1979) and for at least a century and a half served as the major textbook for the anatomy and physiology of the ear.

Du Verney considered the cochlea as the principal organ of hearing. He also stated that the vestibule and the semicircular canals were functional for hearing, a conclusion based on his observations that fishes and birds are able to hear and have a vestibule and semicircular canals but lack a cochlea. He believed that the tortuous passages of the labyrinth were like the tubes of trumpets that augment sounds passing into them and that this thereby aided the excitation of the nerve. Du Verney also was a subscriber to the classical theory of implanted air.
The bony lamina was, in Du Verney's view, a selective mechanism: he perceived it to be broader at the basal end and narrower at the apical extremity of the cochlea as illustrated in his Figures IV and V in Plate $\mathrm{X}-$ Fig. 4. The different kinds of sounds, that is, different frequencies, are distributed along its extent, as described in an eighteenth century English translation:

In short, this lamina is not only capable of receiving the vibrations of the air, but its structure makes it appear credible, that it is sufficient to answer to all their different characters: for it being larger at the beginning of its first convolution than it is at the extremity of the last, where it finishes as in a point, and its other parts diminishing in proportion in bulk, we may suppose that the larger parts may be vibrated without the others participating in that vibration; and therefore they are capable of receiving none but the slower undulations, which consequently answer to grave tones: and that, on the contrary, its narrow parts being agitated, their undulations are quicker, and consequently answer to acute tones. In the same manner that the larger parts of a steel spring form the slowest undulations, and answer to grave tones: and so its narrower parts form quicker and more frequent vibrations, and consequently answer to acute tones. So that in short the spirits of the nerve, which expanded over its substance, receive different impressions which represent in the brain the different appearances of 

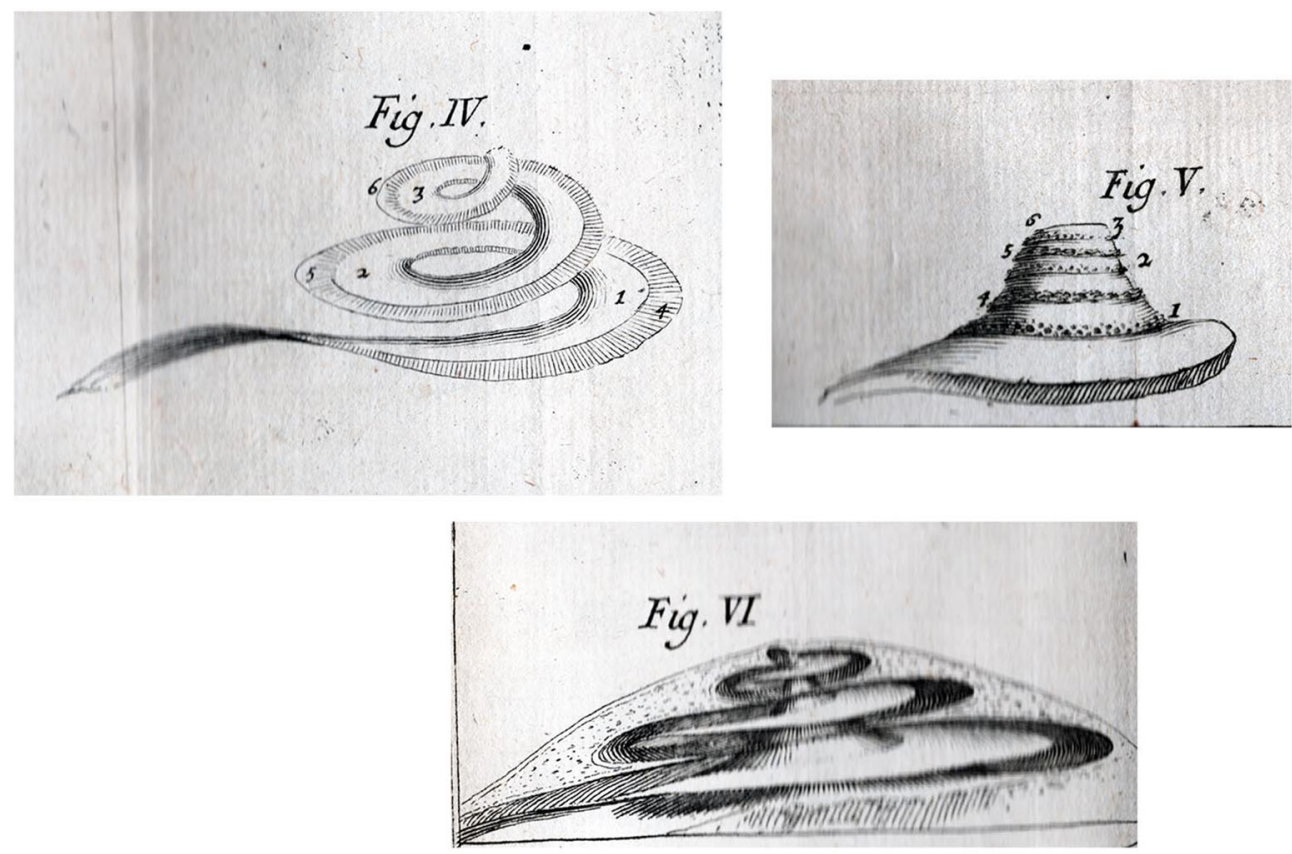

FIG. 4. Plate $X$, figures IV, $V$ and $V I$ from Du Verney (1683). From the library of the author and photograph by the author

tones according to the different vibrations of the lamina spiralis. (Du Verney 1737)

There is a fascinating paradox in Du Verney's contribution concerning tonotopic organization: in short, he got the theory right and the observation wrong. Archives of the period document that Du Verney, in accounting his expenses incurred earlier in the performance of his dissections, included reimbursement requisitions for magnifying glasses and a microscope. Thus we can know that he used magnifying instruments in making his observations, a point which heretofore has not been recognized (Guerrini 2015). It should be noted further that Du Verney's use of magnification is also indicated in his descriptions of his illustrations. For example, in his "Explanation of Plate X," he describes Fig. I as representing "the temporal Bone twice as large as Nature," and he describes Fig. IV as representing "the Lamina Spiralis in the Air much larger than nature." Specifically, his reimbursement memoranda for 1687 and 1691 include reimbursement requests for a microscope and two "very strong" magnifying glasses.

If we ask why Du Verney, who arrived at the right theory, produced incorrect observations in spite of his use of magnifications, the answer lies in the development of scientific technology. Du Verney's observations were made on intact or dissected specimens but not on sectioned and stained material because microtone and staining were not introduced until the end of the eighteenth century (Wilson 1995). One can only surmise that if he had the instruments for better observation, he would have also observed the correct dimensions of the basilar membrane. Du
Verney utilized knowledge of the resonance of a stringed instrument, the lute, which he applied to his anatomical observations of the cochlea (Du Verney 1737). Indeed, resonance underlies his theory of the tonotopic organization of the cochlea: high tones at the apex and low tones at the base. This concept persisted until the latter part of the nineteenth century.

\section{EIGHTEENTH CENTURY}

The concept of tonotopic organization with lowfrequency (grave) tones mediated from the base of the cochlea and high-frequency (acute) tones at the apex persists in Albrecht von Haller's (1708-1777) 1751 publication (Haller vA 1751). Following Du Verney, von Haller describes the osseous lamina as an indefinite number of cords, continually shortening in their lines (lengths of his so-called cords). By that means, they are adapted so that there is a greater variety of acute and grave sounds which vibrate sympathetically; the longest are at the base of the cochlea with the grave sounds, and the shortest near the apex with the acute sounds. Further, he stated that the distinction of sounds no doubt depends upon the rapidity of the tremors of the cochlea and acoustic nerve as they follow one another frequently or slowly over a brief time. For this, it is not necessary that the tremors be numbered by the mind but only that their numbers be different and that this difference excite changes in our perceptions, as described in an 
English translation in 1801 (Haller vA. First lines of physiology. Edinburgh Ad 1801):

It is an elegant conjecture, that since the lamina spiralis forms a true triangle, of which the apex is a very acute angle, it may be supposed to contain an infinite number of cords, successfully shorter, which correspond harmonically with the various acute and grave tones, for that they vibrate in uniform with the greater number of sounds; the longest cords in the base of the cochlea with the gravest sounds; and the shortest cords nearest the apex, with the sharpest sounds. Are sounds perceived in the middle semicircular canals, since there alone are found in all classes of animals? Or are they perceived in the canals, in the cochlea, and in the membrane suspended in the vestibulum? This seems probable. (Haller vA. First lines of physiology. Edinburgh Ad 1801)

This erroneous view of the tonotopic organization of the cochlea should have changed with the publication of Domenico Felice Antonio Cotugno's (17361822) dissertation, presented in 1761 when Cotugno was 25 years old (Cotugno 1761,9 Cap. XCII). Based on his anatomical observations, he theorizes that highfrequency tones are mediated at the base of the cochlea with a continuum so that the low frequencies are mediated at the apex, as described in a 1997 English translation:

The necessity of the cochlea, in which there is a series of parallel and stretched strings, like in a tambourine, is quite evident. The cochlea keeps the nervous filaments it receives from the lamina spiralis together and keeps them parallel and of different lengths. I put the smallest of these strings at the base of the area (basilar membrane) right near the orifice of the scala tympani, where it is narrower. I put the longest ones at the small hook of the area. When a sound is generated, as in the case of the human voice, we may observe that, among all the strings of the tambourine, only one vibrates in unison with the sound; thus, within the cochlea, which is our tambourine, for every sound there is a corresponding and appropriate string that, by vibrating in unison, permits the soul to discriminate sounds. This fact probably explains why the cochlea does not exceed the length of two turns and a half, because in that area there may be an area long enough to get all the possible strings responding in unison to the sounds we hear. Therefore, we perceive the sound by means of the sept, we recognize the tones by means of the cochlea. (Manni and Petrosini 1997)
Cotugno uses the observation of resonance as the basis of his hypothesis of the function of the cochlea. In addition to this first correct demonstration of tonotopic organization, Cotugno is the first to demonstrate that the labyrinth is filled with fluid, not air. This critical discovery was based upon his observations of fresh anatomical specimens. Previous observations had been made on dried specimens in which the fluid of the ear had evaporated (Cotugno 1761; Manni and Petrosini 2010). Cotugno's discovery in the eighteenth century finally negated the theory, derived from classical Greece, of air inside the ear. His recognition that the labyrinth is filled with fluid contributes to the understanding in the nineteenth and twentieth centuries of cochlear function.

However, Cotugno's theory of tonotopic organization was ignored. Cotugno went on to have an illustrious career in medicine, but his correct understanding of the tonotopic organization of the cochlea remained unknown at the time and did not contribute to the scientific discourse.

\section{NINETEENTH CENTURY}

In the nineteenth century, the long-held, dominant and erroneous view of the tonotopic organization of the cochlea in which high tones are mediated at the apex and low tones at the base was finally reversed. Hermann Ludwig Ferdinand Helmholtz (1821-1894) reversed that concept and demonstrated our current view: high tones are mediated at the base of the cochlea and low tones are mediated at the apex. He arrived at this view through an evolution of thought and understanding: the development of his thinking can be followed through an early lecture and the four editions/revisions of his book, Die Lehre den Tonempfindungen als physiologische Grundlage für die Theorie der Musik (Helmholtz 1870), which span the period from 1857 to 1877 . A turning point was his incorporation of the zoologist Victor Hensen's (18351924) measurements of the width of the basilar membrane.

In 1857, Helmholtz gave a lecture on the foundation of music and presented his first formulation of his resonance theory of hearing (Wever 1949; Cahan 2018). This was followed 6 years later by the publication in 1863 of the first edition of Die Lehre den Tonempfindungen als physiologische Grundlage für die Theorie der Musik. This book went through three revised editions, second (first revised) edition in 1865 (Helmholtz 1865), third (second revised) edition in 1870 (Helmholtz 1870), and fourth (third revised) edition in 1877 (Helmholtz 1877). There were two 
English translations: the first was published in 1875 of the third edition (Helmholtz 1875) and the second was published in 1885 of the fourth edition; the latter was reprinted in 1954 (Helmholtz 1954).

Helmholtz established the current concept of tonotopic organization of the cochlea in the third edition of 1870 (Helmholtz 1870). ${ }^{1} \mathrm{He}$ achieved his understanding by utilizing Ohm's law of auditory analysis (Ohm 1843), Mueller's doctrine of specific energy of nerves (Müller 1826), and the anatomical discoveries of Corti (Corti 1851), and Hensen (Hensen 1863). Measurements by Hensen of the basilar membrane were most critical to the formation of Helmholtz's resonance theory of hearing in the third edition (Fig. 5). Hensen observed that the basilar membrane was the more likely resonance structure in comparison with the pillar cells because it varies more markedly in size than the pillar cells: according to his observations, there is about a 12-fold increase in width of the basilar membrane from base to apex.

Helmholtz comments on the use he made of new information in explaining the first appearance of the new tonotopic concept in a footnote (page 218 of the 1875 English translation) as follows:

In the first edition of this book (1863), which was written at a time when the more delicate anatomy of the cochlea was just beginning to be developed, I supposed that the different degrees of stiffness and tension in Corti's rods themselves might furnish the reason of their different tuning. By Hensen's measures of the breadth of the membrana basilaris (Zeitschrift für wissensch. Zoologie, vol. xiii. P. 492) and Hasse's proof that Corti's rods are absent in birds(Hasse 1866) and amphibia, far more definite foundations for forming a judgment, have been furnished, then I then possessed.

Helmholtz further develops his new concept of tonotopic organization in the fourth edition (page 146 of the Dover 1954 reprint of the 1885 English translation):

... the basilar membrane is tightly stretched in the transverse direction from the modiolus to the outer wall of the cochlea but has little tension in the direction of its length because it cannot resist strong pull in this direction ... but if the tension in the direction of its length is infinitesimally small in comparison with the tension indirection of the breadth, then the radial fibers of the basilar membrane may be approximately regarded as forming a system of stretched strings, and the membranous connections as only serving to give a fulcrum to the pressure of the fluid against these strings. ... any exciting tone would set that part of the membrane into sympathetic vibration, for which the proper tone of one of its radial fibers that are stretched and loaded with the various appendages already described, corresponds most nearly with the exciting tone; and thence the vibrations will extend with rapidly diminishing strength onto the adjacent parts of the membrane. The strongly vibrating parts of the membrane would, as has been explained in respect to all bodies which vibrate sympathetically, be more or less limited, according to the degree of damping power in the adjacent parts, by friction against the fluid in the labyrinth and in the soft gelatinous parts of the nerve fillet.

Under these circumstances the parts of the membrane in unison with higher tones must be looked for near the round window, and those with deeper, near the vertex of the cochlea, as Hensen also concluded from his measurements. That such short strings should be capable of corresponding with such deep tones, must be explained by their being loaded in the basilar membrane with all kinds of solid formations; the fluid of both galleries in the cochlea must is also be considered as weighting the membrane, because it cannot move without a kind of wave motion in that fluid. (Helmholtz 1954)

It took Helmholtz synthesizing microscopic anatomy, physics, and acoustics to develop the concept of base-to-apex high tone to low tone tonotopic organization. Helmholtz is the synthesizer.

It is surprising that Helmholtz, who was very scholarly (Cahan 2018), never refers to Cotugno's conclusion in his dissertation of 1761 of the base-toapex high tone to low tone tonotopic organization.

This tonotopic theory of high to low tones from base to apex becomes the present model. In Helmholtz, however, it is still a theory because it has not been shown to be related to the physical properties of the basilar membrane, the physiology of hearing, or the psychoacoustics of hearing.

During the late nineteenth century, several publications sought to correlate the pathology of the cochlea in man with hearing. C. Hubert Hurst, Ph.D. (Hurst 1894), an English anatomist, in 1894 mentioned that injuries of the apex of the cochlea caused a loss of hearing for low tones but provided no details.

Pathological evidence, with the details of which I am not acquainted, shows that injury-or at any rate some injuries-to the apex of the cochlea lead 


\begin{tabular}{|c|c|}
\hline n der Wurzel entfernt & $\begin{array}{r}\text { Breite der } \mathrm{A} \\
\quad \quad 0,041\end{array}$ \\
\hline $26 \quad, \quad, \quad,, \quad,, \quad$, & $325 \mathrm{Mm}$ \\
\hline iertel der 1 . Windung & $69 \mathrm{Mm}$. \\
\hline Wrind & 0 \\
\hline & 0 , \\
\hline & \\
\hline Am Hamulus & . $0,495 \mathrm{Mm}$. \\
\hline
\end{tabular}

FIG. 5. Hensen's measurements of the basilar membrane which was considered the more likely resonance structure; according to his observations there is about a 12-fold increase in width of the basilar membrane from base to apex (Hensen 1863)

to a deafness to low tones, while the ear may still remain sensitive to high ones. (Hurst 1894)

There were at least three reports (Stepanow 1886; Moos and Steinbrügge 1881; Gruber 1885) concerning various forms of human cochlea pathology and the patients' hearing and one report based on guinea pig experiments (Stepanow 1888). These studies had critical design flaws in that the stimuli and the responses were not controlled, and the histology was inadequate due to artifacts. The results were conflicting and did not prove or disprove Helmholtz's theory of tonotopic organization.

\section{TWENTIETH CENTURY}

The twentieth century brought about advances in the understanding of the physics of the basilar membrane, the physiology of the cochlea, and the correlation of cochlear function with hearing in animals and man. Georg von Békésy (1899-1972) commencing in 1928 published a series of studies which culminated in his being awarded the Nobel Prize in Physiology or Medicine ${ }^{2}$ for his research on the function of the cochlea in the mammalian hearing organ (Wever 1949). His initial studies utilized model membranes which consisted of covering a hole on a metal plate with a rubber film and stimulating it with pure tones. Through this model, he demonstrated that the place of maximum amplitude of vibration was dependent upon the frequency of the stimulus (Békésy 1928) (Fig. 6a), in English translation (Békésy 1960a):

From the intermediate curves it may be seen that in the course of this movement the fluid above the membrane and on the left side will be sucked in the direction of the solid arrows. When the

\footnotetext{
2 Róbert Bárány (1876-1936), also a Hungarian, in 1914 was the first to be awarded a Nobel Prize in the area of otology; it was in physiology or medicine based on his work on the physiology and pathology of the vestibular apparatus.
}

membrane reverses its direction the fluid will be displaced to the right as indicated by the broken arrows.

In this manner the vibration of the membrane near the place of resonance, where the displacement is the greatest, produces a transporting of fluid near the surface in a direction from the higher tuned resonators to the lower tuned ones. This transported fluid of course must return, and in this way the eddy arises. The same thing takes place on the lower side of the membrane, though the form of motion is a mirror image of that of the upper side. This situation accounts for the variation in the location of the eddy as a function of frequency, as well as for the other phenomena mentioned. Because the vibration has its maximum amplitude at the place where the eddy appears, a perforation of the membrane always occurs there. (Békésy 1960a)

In these studies that utilized models, optimal resonance at different places along the basilar membrane model was directly observed. These studies demonstrated for the first time the correctness of the theory of resonance underlying tonotopic organization.

The next crucial step was to determine whether the same phenomenon would occur in a biological specimen, that is, in the cochlea of various animals including man. To explore this question, von Békésy utilized human temporal bones: he removed the stapes and replaced it with a rubber membrane cemented to a small brass ring over the oval window. Vibrations were produced from the driving unit of a loudspeaker, and these were transmitted to the basilar membrane by an artificial stapes which was a knob attached to the rubber member. This 1943 study demonstrated the patterns of vibration for various frequencies on the basilar membrane of a cadaver specimen (von Békésy 1943). The results are presented in Fig. 6b, and von Békésy describes his observations in two passages, here in English translation, as follows (Békésy 1960a): 

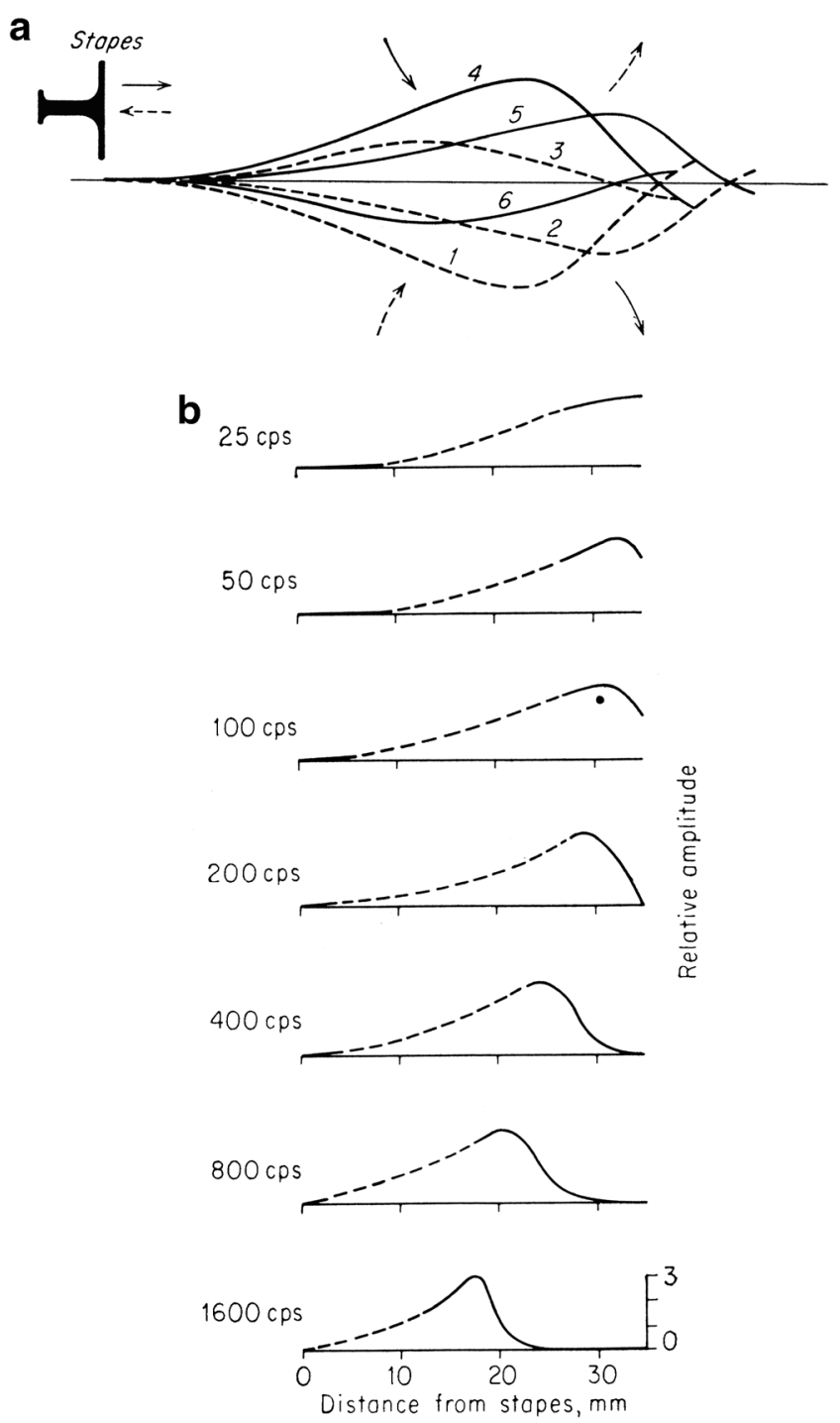

FIG. 6. G. von Békésy's illustration of tonotopic vibration in a simulation model (a) and in a human temporal bone (b) (von Békésy 1960a)

The vibrations observable through the microscope were relatively large, and the next step was to discover whether nonlinear distortions appeared in the measured amplitudes. The data showed that the amplitude of vibration of the cochlea partition, as observed at a particular point, increased exactly in proportion to the amplitude of the vibration of the loudspeaker system, so that no distortion was present.

... frequencies below approximately $30 \mathrm{cps}$, the whole cochlea partition near the helicotrema vibrated with almost the same amplitude. As the frequency was raised, however, the vibrations moved away from the helicotrema until, at frequencies above $800 \mathrm{cps}$, no further vibrations could be seen in the exposed spiral. The measured amplitudes of vibration, expressed in volume displacement per millimeter of length of the partition, constitute the ordinate in figure 11-43. [here Fig. 6b]. This scale is arbitrary for each individual frequency. The abscissa represents the distance from the stapes to the measured point. The distances were determined by noting the direction of the cochlear duct and converting the angle into distance by means of a chart of the cochlea, as described on page 29. (Békésy 1960a)

Through von Békésy's experiments, the physical properties of the basilar membrane were determined to be consistent with the concept of the cochlea's tonotopic organization in which high-frequency tones have their greatest effect at the base and the lowfrequency tones at the apex of the cochlea.

Jozef John Zwislocki (1922-2018) in 1946 (Zwislocki 1946) and 1950 (Zwislocki 1950) added to the understanding of the physical properties allowing for the tonotopic organization of the cochlea. Using a rubber model similar to that used by von Békésy 
(Békésy 1928), Zwislocki hypothesized that the analytic action of the cochlea depends upon only two variables, the elasticity and the dampening of the basilar membrane. He considered hydrodynamic principles and concluded that every tone produces a wave that travels up the cochlea, reaches a maximum amplitude at some position, and then rapidly falls away. Location of the maximum variation to frequency is near the base for high tones and toward the apex for low tones.

A major advance in the twentieth century for the understanding of tonotopic organization was based on the discovery of the electrophysiological properties of the cochlea to sound. This electrical activity was first demonstrated in 1930 by Ernest Glen Wever (1902-1991) and Charles W. Bray II (1904-1982) who, in their experiments, discovered the electrical physiological properties of the ear in response to sound, the Wever-Bray effect (Wever and Bray 1930a; Wever and Bray 1930b) which is now referred to as the cochlear microphonic. They misattributed these potentials to the auditory nerve, albeit expressing some uncertainty about that conclusion. They discuss their results as follows:

The results so far obtained in this investigation bear upon the question of the relation between the qualitative aspect of the stimulus and the nature of the nerve response. It was found that sound stimuli applied to the ear of the animal set up in the auditory nerve action currents of frequencies corresponding to those of the sound waves. These action currents, after amplification, were audible in the receiver as sounds which, so far as the observer could determine, were identical with the original stimulus.

Speech was transmitted with great fidelity. Simple commands, counting, and the like were easily received. Indeed, under good conditions the system was employed as a means of communication between operating and sound-proof rooms.

A simple tone sounded into the cat's ear gave rise to that tone in the receiver. The observer was able to detect no difference in pitch between this tone and the original stimulus. The range of frequencies to which response can be obtained has not as yet been thoroughly investigated, but the response has been observed to tones as low as 125 and as high as $4100 \sim /$ sec. There was manifested a high degree of tonal discrimination: e.g., if two tones of adjacent frequencies, such as 3200 and $3300 \sim$, were given in succession, the observer could report accurately which was the higher.

These facts show, then, that in the nerve as a whole the frequency of response is correlated with the frequency of stimulation.
There was evidence also of a correspondence between the intensity of response in the nerve as a whole and the intensity of stimulation.

The above results are not what have been expected on the basis of recent work on other sensory nerves. The nerve responses recorded by Adrian and others on stimulation of the end-organs of pressure, pain, vision, and muscle-sensitivity, have in every case shown frequency of nerve impulse to be correlated with intensity of stimulation. Here, on the contrary, we have found frequency of impulse correlated with frequency of stimulation. Because of the divergence of our findings from what is beginning to be accepted as a general law of sensation, and the obvious suspicion aroused by what appears to be a direct correlation of stimulus and end-effect, it is necessary to produce evidence eliminating every possibility of artifact, and to supply checks beyond what have ordinarily been considered necessary in experiments of this nature in order to establish the results as in reality due to action currents in the nerve set up in the response of the ear to sound. (Wever and Bray 1930b)

This interpretation by Wever and Bray that the electrical response they observed was the nerve responding to sound turned out to be inaccurate and was quickly challenged (Adrian et al. 1931). Hallowell Davis (1896-1992), Arthur J. Lurie (18931993), Moses H. Lurie (1893-1979), and Leon J. Saul (1912-1992) (Davis et al. 1934) ${ }^{3}$ demonstrated through a series of experiments, including studies in deaf white cats, the effect of anoxia, pithing of the basilar membrane, and lesions of the nerve of hearing, that the cochlear microphonic is the result of stimulation of the hair cells:

The cochlear response is interpreted as arising in the sensory cells of the organ of Corti as a result of mechanical deformation. (Davis et al. 1934)

Davis (Davis 1935) then showed that the WeverBray effect of electrical response has two components: The first is the cochlear microphonic, a specific electrical response of the cochlea that is synchronized with the acoustic signal. The second is the action potential of the cochlear nerve. He then utilized the cochlear microphonic to demonstrate the resonance properties of the cochlea in his Figure 13 (Fig. 7).

XII. EVIDENCE FOR SPECIFIC RESONANCE: Fig. 13 shows average curves from guinea pigs, the solid curve representing data from the round

\footnotetext{
3 My appreciation for this information to Louise Collins, Director Massachusetts Eye and Ear Library
} 


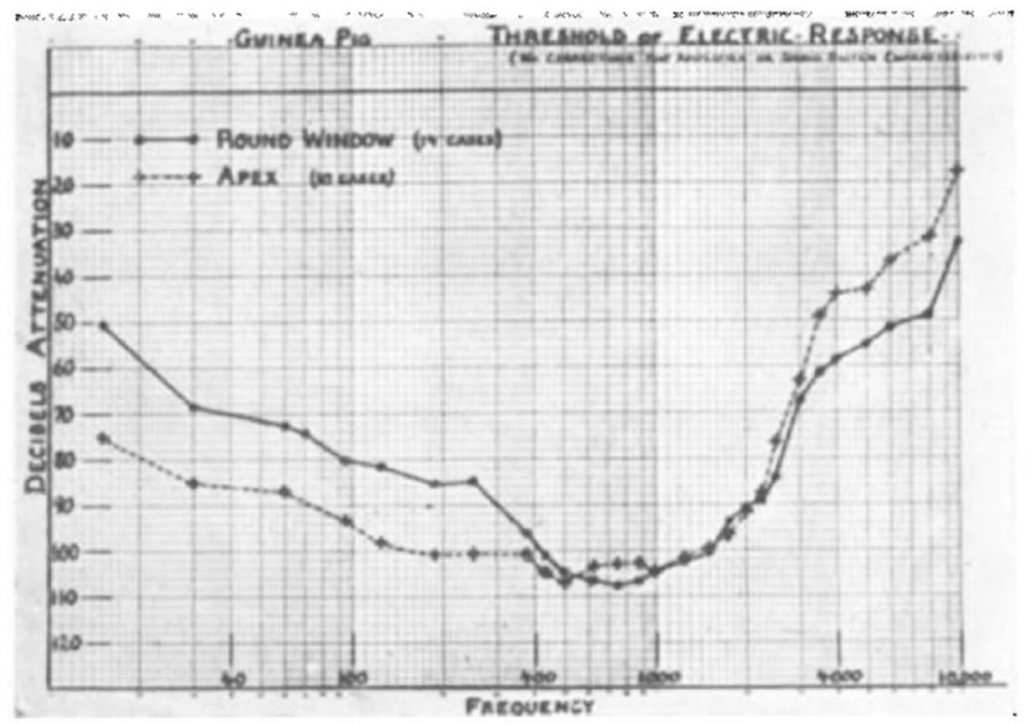

FIG. 13. Comparison of thresholds of electrical response from round window and from apex of cochlea in guinea pigs. No corrections. Note that the sensitivity is greater for high tones at the round window than at the apex, and greater for low tones at the apex than at the round window. ${ }^{36}$

FIG. 7. H. Davis' figure 13 showing physiological evidence for specific resonance (Davis 1935). Reproduced from The Journal of the Acoustical Society of America 1935; 6:205-15, with the permission of the Acoustical Society of America

window, while the dotted line represents the apex. In the guinea pig, the cochlea is exposed in the inner ear in such a way as to make the apical region readily available for experimentation. It is evident that there is a much lower threshold of response to low tones at the apex and to high tones at the round window. ... These data show conclusively that the cochlea is tuned in some fashion from end to end, the low tones being represented toward the apex and the high tones toward the base. (Davis 1935)

The recognition of the electrophysiological properties of the ear leads to the report of Tasaki et al. of 1952 (Tasaki et al. 1952), which provides understanding of the physiological basis of the tonotopic organization of the cochlea with greater electrical response to higher frequencies at the base and greater electrical response to lower frequencies at the apex. This is illustrated in Figure 9 of their 1952 report (Tasaki et al. 1952) in which this is demonstrated in the guinea pig cochlea (Fig. 8).

Concurrent with these advances, and to fulfil their implications, the question needed to be answered is whether these physical, anatomical, and electrophysiological discoveries actually relate to human hearing of discrete frequencies. A most significant advance of the twentieth century was to answer that question whether this basic science relates to hearing as human beings experience it.

An anatomist at The Johns Hopkins School of Medicine, Stacy Guild, Ph.D. (1890-1966), et al., in 1931 (Guild et al. 1931) and 1932 (Guild 1932), described three conditions which were necessary to ascertain the function of the human cochlea. These were as follows: first, to have accurate human temporal bone histology; second, to have a sufficient number of temporal bone specimens so as to be able to note the variation in neural innervation and ganglion cells along the length of the cochlea duct; third, to have an accurate quantitative assessment of human hearing. These three requirements were achieved as follows: (1) the histological demands through Guild's development of excellent histological preparations; (2) sufficient data through testing of many patients admitted to the Johns Hopkins hospital, testing their hearing while still alive, and collecting their temporal bones at autopsy; (3) accurate quantitative assessment of human hearing through the Johns Hopkins' patients undergoing objective hearing testing with the Western Electric 1A Audiometer. Western Electric patented the electric audiometer in 1914 and, in 1922, produced the first commercially available electronic audiometer for the measurement of the sensitivity of hearing, the West- 


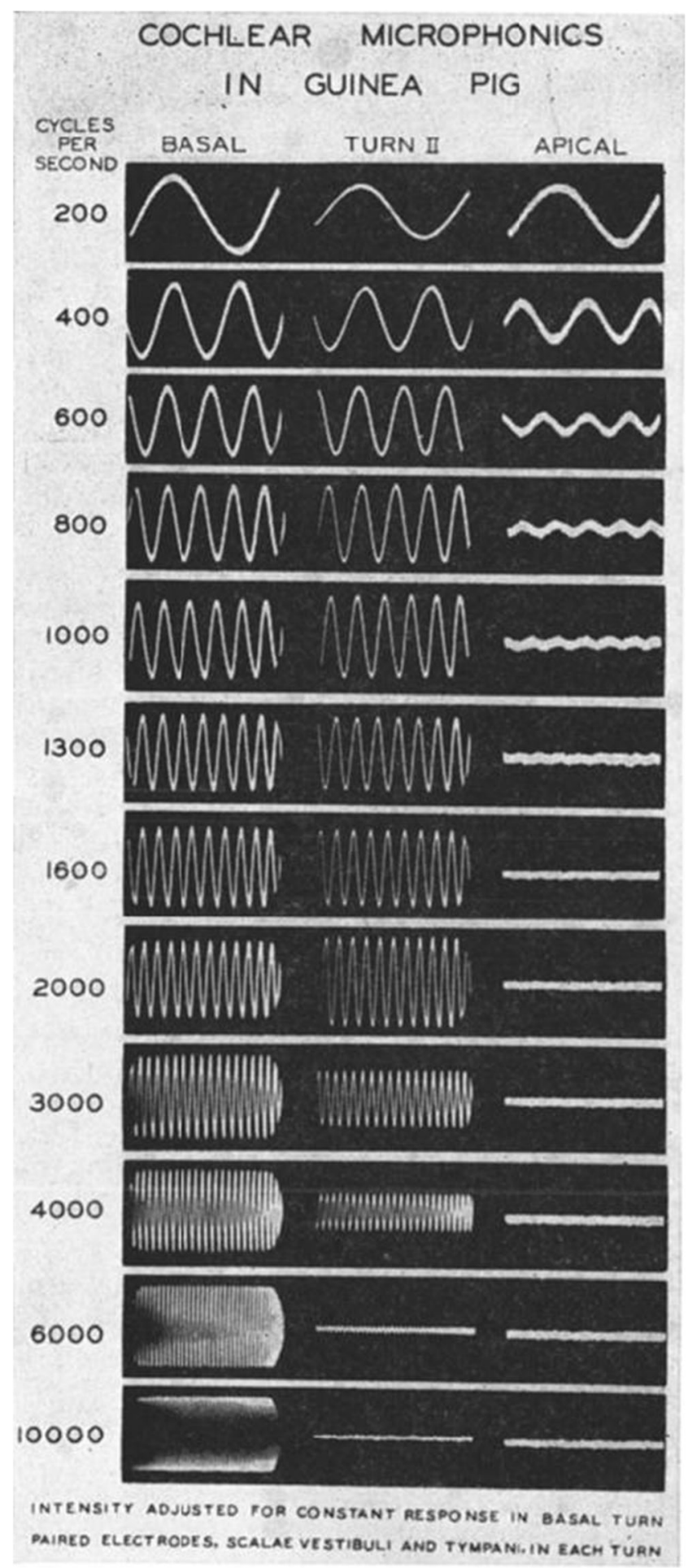

FIG. 8. From Tasaki et al. (1952). Reproduced from The Journal of the Acoustical Society of America 1952; 24:502-19, with the permission of the Acoustical Society of America

ern Electric 1-A. Designed by E. P. Fowler and R. L. Wegel (Fowler and Wengel 1922), it allowed for hearing testing from 32 through 16,384 Hz. For the Hopkins studies, the Western Electric 1-A Audiometer was mounted on wheels so that it could be taken to the ward to test the patients before they died.
Guild devised a system of two-dimensional graphic reconstruction of the three-dimensional cochlea which clearly shows the distribution of cochlear elements throughout the length of the coiled cochlea duct (Fig. 9). The tonotopic properties of the human cochlea could be clearly seen in these twodimensional graphic reconstructions. Individual pa- 
a

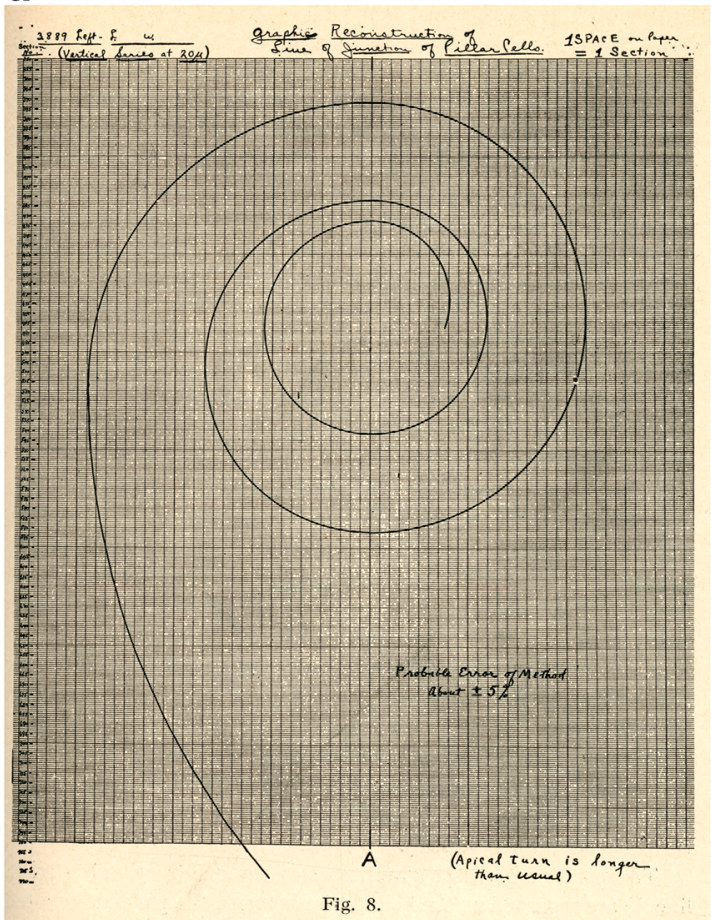

b

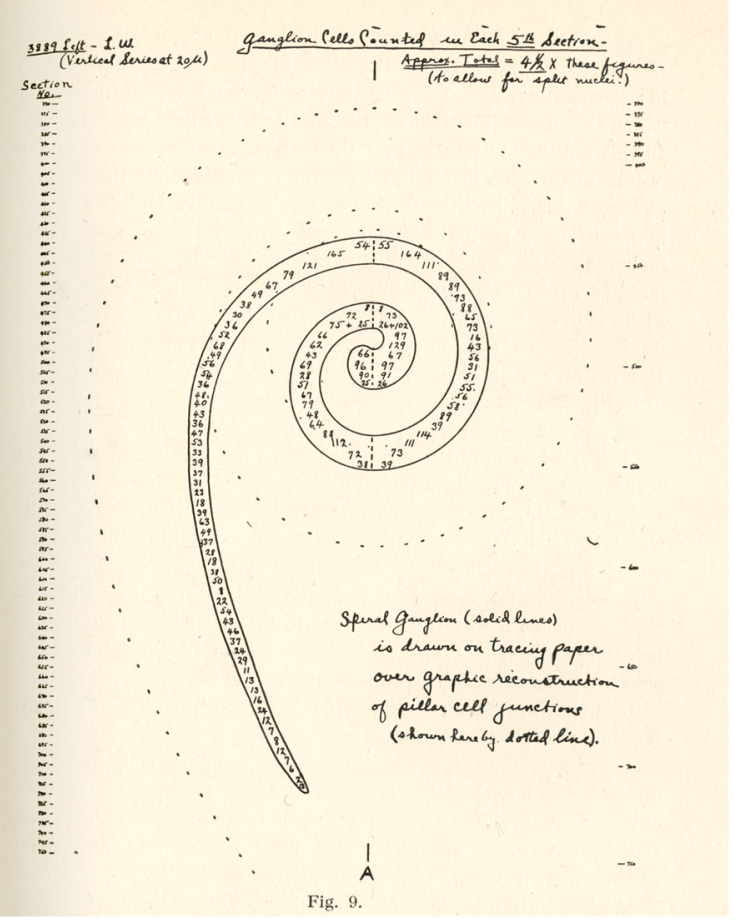

FIG. 9. Illustration of the method of graphic reconstruction of the cochlea showing the spiral ganglion cells, solid lines. a The method of graphic reconstruction reduced from a 20-in.-wide graph paper. b Reconstruction of spiral ganglion cells in specimen \# 3889 left. Figures 8 and 9 in Guild et al. (1931). Reproduced with permission from Acta oto-laryngologica 1931; 15:269-308: www.tandfonline.com

tient data from the histological analysis of the temporal bone and results of audiological testing were used to generate these reconstructions. An example is seen in figure 15 from the 1931 article (Guild et al. 1931) (Fig. 10).

Guild saw in this new device, the Western Electric 1-A Audiometer, which was developed to test hearing for the purposes of a telephone company and of which there were at the time perhaps no more than two or three in existence, the potential to answer a major scientific question: do human beings really hear tones through tonotopic organization? He applied the device's accurate behavioral study to understanding of the anatomy of the cochlea and verified the theory of the tonotopic organization.

The audiogram in Fig. 10 shows an average high tone loss in three ears from 2048 to $4096 \mathrm{~Hz}$ and no response at $8192 \mathrm{~Hz}$ (solid line) which is compared with the average hearing of young adults with good hearing (dashed line). The anatomical data of the normal hearing group and the high tone loss group are compared in a table which shows the average number of ganglion cells per millimeter of the length of the organ of Corti by region. Overall, the high tone loss group had on the average $76 \%(19,538 / 25,614)$ fewer ganglion cells than those with good hearing. The difference in fewer ganglion cells in the lower basal region was $62 \%(579 / 924)$, in the upper basal region $80 \%(862 / 1076)$, in the lower middle region $93 \%$ (854/971), and in the upper middle plus apical region $80 \%(403 / 502)$. These observations are congruent with the location of high tone perception at the base of the cochlea because that is where there is the greatest difference between ears with good hearing and ears with a high tone loss. Unfortunately, there is no information concerning variance which would be required for a twenty-first century report.

These data are the first to relate pathological anatomical findings with hearing so as to locate high-tone perception at the base and low-tone perception toward the apex:

There are differences in the average density of innervation of corresponding regions of the organ of Corti in groups of ears with average differences in the acuity of hearing for tonal regions. These differences are of sufficient degree to indicate definitely that the relative density of innervation of the region of the organ of Corti stimulated by any given tone is an important factor in the relative acuity with which that tone is perceived. Analysis of the evidence from the groups indicates that the regions of the organ of Corti most concerned the perception of all tones below 3000 cycles are located in the upper basil, the middle or the apical turns, and not the regions of the lower basal turn is 


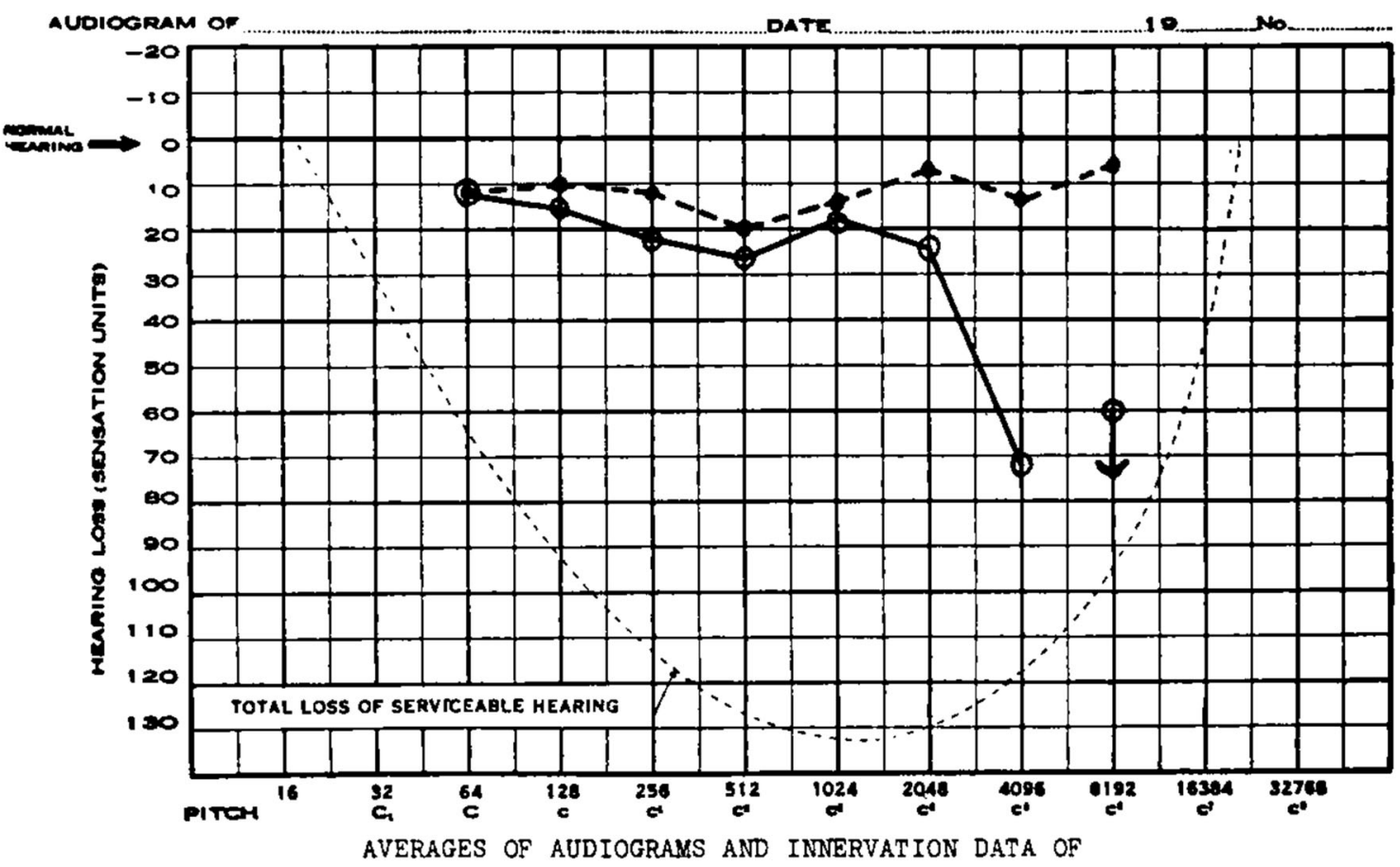

A. FOUR EARS OF YOUNG ADULTS WITH GOOD HEARING; AND

B. THREE EARS WITH MARKED LOSS OF HEARING FOR HIGH TONES

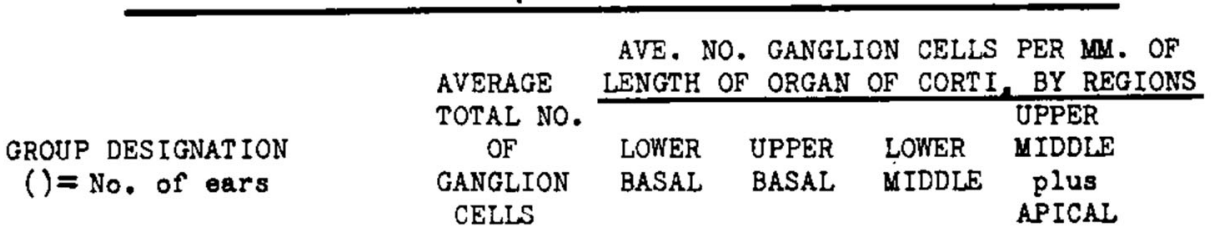

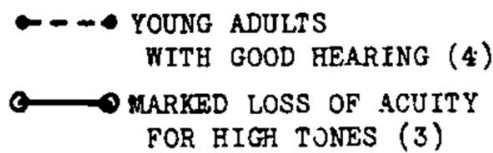

$\begin{array}{rrrrr}25,614 & 934 & 1076 & 971 & 502 \\ 19,538 & 579 & 862 & 854 & 403\end{array}$

FIG. 10. Individual patient data from the histological analysis of the temporal bone and results of audiological testing. Figure 15 in Guild et al. (1931). Reproduced with permission from Acta oto-laryngologica 1931;15:291. www.tandfonline.com

the one most concerned with the reception of tones over frequency of C(Wever 1949) (4096 ) and higher. (Guild et al. 1931) (Fig. 11)

The 1931 (Guild et al. 1931) and 1932 (Guild 1932) articles were followed by a more detailed article by Crowe et al. in 1934 (Crowe et al. 1934) which graphically demonstrated in two dimensions the tonotopic organization of the human cochlea based on the multiple correlations of human temporal bone pathology and quantitative audiometry obtained with the Hopkins Western Electric 1-A Audiometer. They concluded:

"This publication is a correlation of the clinical and pathological findings in 79 ears whose audiograms show impairment of hearing limited to the high tones. A proper control for this study has been established by comparing the middle and inner ear lesions in ears with known good hearing for all tones with the lesions found in our cases with impaired hearing. The control group numbers about 200 ears. Our observations prove very definitely that the receptors for high tones are located in the basal turn of the cochlea. Threefourths of the ears with impaired hearing for high tones have lesions of the basal turn more extensive and severe than in any of the control group. (Crowe et al. 1934)

These observations offer no definitive evidence from human studies for a discreet locus for the lowfrequency tones. The reason is that the higher the frequency, the smaller the region of cochlear involvement: that is, the region of high tone perception is substantially more discreet than that of low-frequency tones, where the area of cochlear stimulation is much larger (Wever 1949; Wever and Lawrence 1949). This 


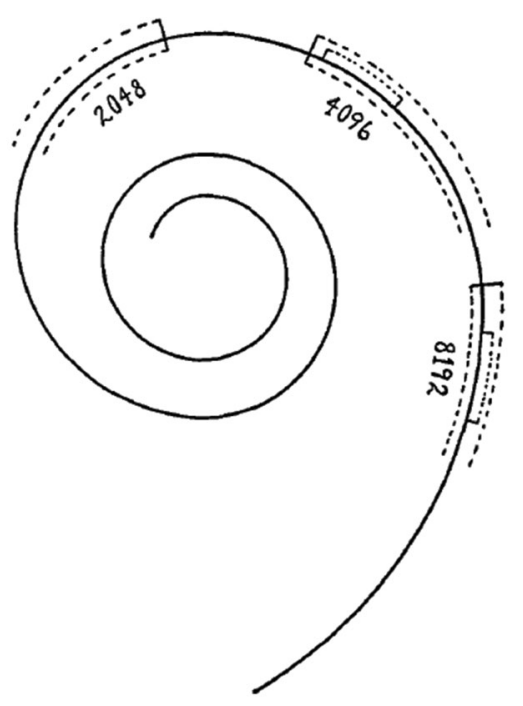

Frg. 44. Spiral diagram of the cochlea showing the localization indicated by our material. The smaller areas marked out for 4096 and 8192 d.v. are those indicated by Ciocco's statistical analysis of the spiral graphs.

FIG. 11. These data are the first to relate the anatomical findings with hearing so as to locate the high tones at the base and the low tones toward the apex. Figure 44 in Crowe et al. (1934). Reprinted with permission from Johns Hopkins University Press

study also showed that over-stimulation by lowfrequency sound destroys a larger portion of the cochlear duct than high-frequency sound, an observation congruent with the anatomical difference noted in the low-frequency reception region and the high-frequency reception region (Wever 1949; Smith and Wever 1949).

Harold Schuknecht (1917-1996) and Dewey Neff (Schuknecht and Neff 1952) (1912-2002) undertook their 1952 animal studies because there was scant evidence for determining what hearing loss would result from damage to receptor or neural elements in the apical portion of the cochlea. Through condition- ing with an avoidance response in cats with an only hearing ear, behavioral audiograms were obtained before and after a lesion was created at the apex of the cochlea. This was accomplished using the operative techniques developed by Julius Lempert (Lempert 1938) (1891-1968) of creating a small fenestra which thinned the bone, which then enabled the membranous cochlea to be entered with a small needle. At this point, Schuknecht and Neff carried out various apical lesions. The temporal bones of the cats were obtained after the post-lesion audiograms and histologically analyzed with serial sections (Neff 1984). They concluded:
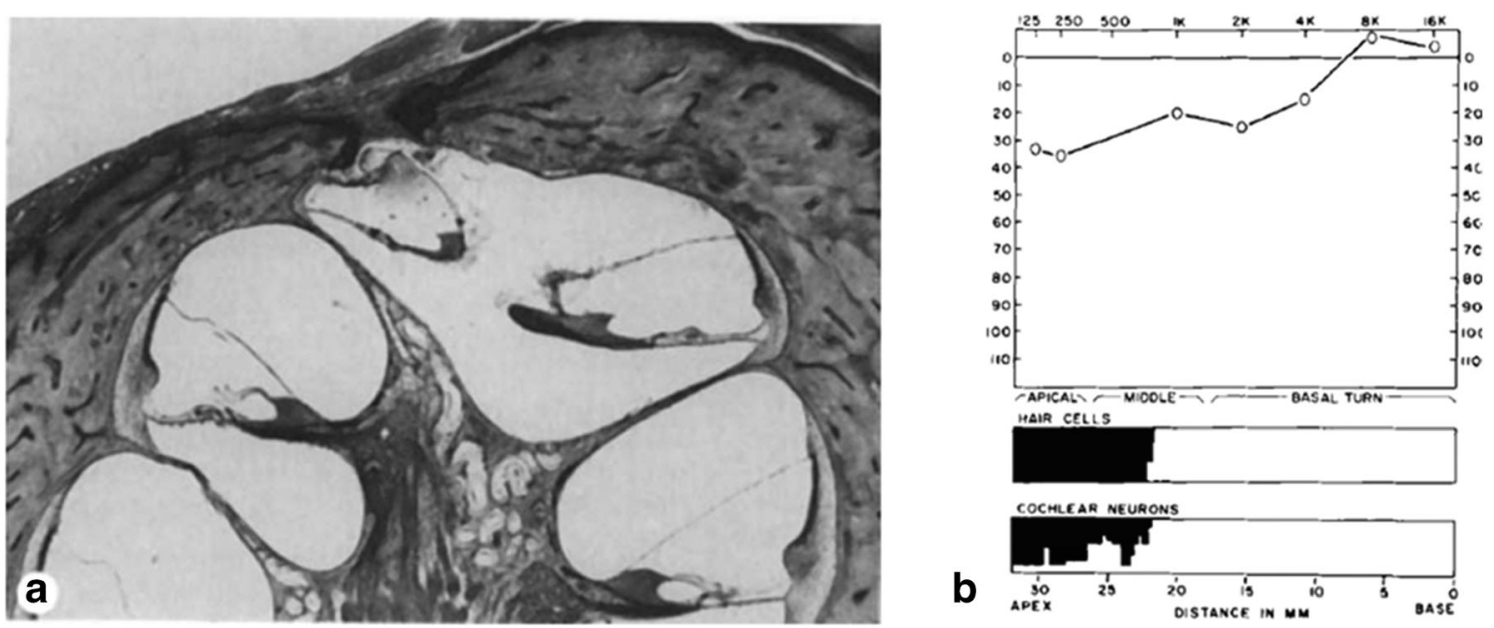

Fig 2. Results in cats with apical lesions. A) Surgical lesion. B) Behavioral audiogram. (Reprinted with permission. ${ }^{\text {) }}$

FIG. 12. Schuknecht and Neff (1952) demonstrated the hearing losses after apical lesions in the cochlea. Figure 2 in Neff 1984 . Reproduced with permission from Acta Oto-Laryngologica, 1952, 42:3, 263-274. www.tandfonline.com 
The results obtained indicate that, at near threshold intensities, frequencies below $500 \mathrm{c}$. p. s. excite receptors only in the apical turn of the cochlea - at least, it is only in this region that the effect they produce is sufficient to set off the neural activity necessary for sensory discrimination. As intensity is increased the low frequencies appear to arouse activity over a wide area of the cochlea so that, at intensities 20 to $30 \mathrm{db}$. above threshold, they are producing excitation at least as far towards the base as the lower middle turn of the cochlea. (Schuknecht and Neff 1952) (Fig. 12)

These results based on combined behavioral and anatomical observations are consistent with the physical observations of von Békésy (von Békésy 1943; Békésy 1960b), which showed the very broad vibration pattern of the cochlear partition when stimulated with low-frequency tones. These results were confirmed in the late twentieth century by Donald Greenwood (Greenwood 1990) in various living mammals and in human cadaver material and by Marcus Müller (Müller 1996) in the Mongolian gerbil.

\section{CONCLUSION}

The correct understanding of hearing, and of the tonotopic organization of the cochlea in particular, developed from speculation by the ancient Greeks to our contemporary knowledge, based on a synthesis of several of the basic sciences and on experiment and observation. This accurate understanding has led to a major advance in the care of the deaf and hearing impaired: the cochlear implant. The first implants stimulated the whole cochlea, but as development on the device was continued, realization that the cochlea would respond more appropriately by stimulation of discrete regions led to the development of our current generation of cochlear implants (Mudry and Mills 2013). The cochlear implant threads a series of electrodes through the cochlea, and the electrodes are programmed so those nearest the apex are activated by low tones and vice versa. Today's implant itself is a model of the tonotopic organization of the cochlea and is based upon it.

Helmholtz arrived at an accurate view of the tonotopic organization through a synthesis of studies of the physics of sound, including his own, and anatomical observation. von Békésy furthered the concept with the application of physics to the observation of models and anatomical specimens of the ear. Wever and Bray discovered the electrical response to sound of the ear, and Davis et al. identified the components of the electrical response.
Building upon the cochlear microphonic, Tasaki demonstrated that the physiological responses were consistent with the base-to-apex high-to-low-tone tonotopic organization. Guild proved that the tonotopic organization of the cochlea was responsible for pure tone hearing in humans.

The cochlear implant applied centuries of scientific endeavor for the care of patients. The pursuit of basic science transformed the concept of tonotopic organization from theory to fact and in the service of humankind.

\section{ACKNOWLEDGMENTS}

I am grateful for having had the privilege of knowing in varying degrees and learning from a number of the investigators who are responsible for the developments discussed in this paper, including $\mathrm{H}$. Davis, S. Guild, H. Schuknecht, D. Neff, J. Tasaki, G. von Békésy, G. Wever, and J. Zwislocki. My thanks to Arlene Shaner of the New York Academy of Medicine Library, Louise Collins of the Massachusetts Eye and Ear Library, and the Biblioteca Apostolica Vaticana for enabling my research and location of illustrations. I am forever grateful for the insightful and wise editing of Yvonne Korshak.

\section{REFERENCES}

Adrian E, Bronk D, Phillips G (1931) The nervous origin of the Wever and Bray effect. J Physiol 73:2P-3P

AJita R 2015 Galen AND his CONTRIBUtion to ANATOMY: A REVIEW

Alcmaeon (2018) Alcmaeon. http://Platostanfordedu/Entries/ ALCMAEON/\#OTH2010. ACCESSED 16 Apr 2018

Aristotle (2010) translated by Smith J. De Anima (On the soul) Book II. http:/ / psychclassicsyorkuca/Aristotle/De-anima/de-anima $2 \mathrm{htm} 2010$

Asherson N (1979) A bibliography of editions of Du Verney's Traite de l'Organe de l'Ouie. Published between 1683 \& 1750. H.K. Lewis, London

Bauhin C 1605 Theatrum anatomicum. Dietz: Ziegenhain \& Nidda

VON BÉKÉSY G (1928) Zur Theorie des Horens; Die Schwingungsform der Basilarmembran. Phys Z 29:793-810

VON BÉKÉsy G (1960A) Vibratory pattern of the basilar membrane. In: Wever E (ed) Experiments in hearing, vol 421. McGraw-Hill Book Company, New York, p 47,48

VON BÉKÉSY G (1960B) Resonance and decay process in the cochlear partition. In: Wever E (ed) Experiments in hearing. McGraw-Hill Book Company, New York, pp 446-469

Békésy GV, Rosenblith WA (1948) The early history of hearing-observations and theories. J Acoust Soc Am 20:727748

CaHan D (2018) Helmholtz: a life in science. The University of Chicago Press, Chicago and London

Castiglioni A (1941) A history of medicine. Alfred Knopf, New York

COÏTER V 1572 EXTERNARVM ET INTERARVM PRINCIPALIVM HVMANI CORPORIS PARTIVM TABVLE: ATQVE ANATOMICE EXERCITATIONES OBSERVATIONESQVE VARIÆ, NOVIS, DIVERSIS, AC ARTIFICOSISSIMUS FIGVRIS ILLVSTRATE, PHILOSOPHIS, MEDICIS, IN PRIMIS AUTEM ANATOMICO STUDIO ADDICTIS summe vTiles. Noribergae: In Officina TheOdorici Gerlatzeni 
Corti AM (1851) Recherches sur L'Organe de l'ouie des Mammifères. Zeitschrift für wissenschaftliche Zoologie von Siebold und Kölliker 3:106-169

Cotugno D 1760 De aquaeductibus auris humanae internae anATOMica dissertatio NeApoli: [S.N.]

Cotugno D (1761) De aquaeductibus auris humanae internae anatomica dissertatio. Neapoli, Ex Typographia Simoniana

Crowe S, Guild S, Polvogt L (1934) Observations on the pathology of high-tone deafness. Bull Johns Hopkins Hosp 54:315-379

DAVIS H (1935) The electrical phenomena of the cochlea and the auditory nerve. J Acoust Soc Am 6:205-215

Davis H, Derbyshire AJ, Lurie MH, Saul LJ (1934) The electrical response of the cochlea. Am J Phys:311-332

Du Verney GJ (1683) Traite de l'organ de l'ouie; contenant la Structure, les Usages et les Maladies de toutes les parties de l' Oreille. Chez Estienne Michallet ruë S. Jacques à l' Image S. Paul, Paris

Du Verney GJ (1737) A treatise of the organ of hearing, containing the structures, the uses, and the diseases of all the parts of the ear. Translated from the French. Samuel Baker, at the Angel and Crown in Russell Street, Covent-Garden, London

EMPEDOCLES 2010 EMPEDOCLES: FRAGMENTS AND COMMENTARY TRANSLATOR Fairbanks A. In: A F, ED. hTtP://historyhanovere DU/TEXTS/ presoc/emp htm. Hanover Historical Texts Project ed

FINGER S (1994) The ear and theories of hearing. In: Origins of neuroscience. Oxford University Press, New York, pp 108-123

Fowler E, Wengel R (1922) Presentation of a new instrument for determining the amount and character of auditory sensation. Trans Am Otol Soc 16:105-103

Galen 1968 Galen on tHe usefulness of the parts OF THE BODY. Translated From the GreEk With an INTRODUCTION AND COMMENTARY by Margaret Tallmadge May. Ithaca: Cornell University Press, KingSPORT Press:403

Galilei G 1638 Discorsi e dimostrazioni matematiche intorno À due NUOUE SCIENZE ATTENENTI ALLA MECANICA \& I MOUIMENTI LOCALI ... CON VNA APPENDice DEL CENTRO DI GRAUITÀ D'ALCUNI SOLIDI. LeIDA: APPRESSO GLI ElSEUIRII:96-107

Gallie G 1914 Translated from the Italian and Latin into English by Crew H, De Salvio A. Dialogues concerning two new sciences. New York: Macmillan:97-108

GREENWOOD DD (1990) A cochlear frequency-position function for several species-29 years later. J Acoust Soc Am 87:2592-2605

Gruber J (1885) Ein Fall von Ausstossung des die oberen zwei Windungen enthaltenden necrotischen Schneckengehäuses mit Genesung des Kranken und nur theilweisem Verluste des Hörvermögens auf dem betreffenden Ohre. Monatschr Ohrenh 4:225-229

GUERRINI A (2015) The courtiers' anatomists: animals and humans in Louis XIV's Paris. The University of Chicago Press, Chicago and London

Guild S (1932) Correlations of histologic observations and the acuity of hearing. Acta Oto Laryngol Stockholm 17(2):207-249

Guild S, Crowe S, Bunch C, Polvogt LC (1931) Correlations of differences in the density of innervation of the organ of Corti with differences in the acuity of hearing, including evidence as to the location in the human cochlea of the receptors for certain tones. Acta Otolaryngol 15:269-308

Haller va 1751 Primae lineae physiologiae in usum praelectionum ACADEMiCARVM. GotTINGaE: VANDENHOECK

Haller va. First lines of physiology. Edinburgh Ad 1801 Neill \& Co:240-1

Hasse C 1866 De cochlea AVIUM. Schrift d UnIV Zu Kiel;XIII:15

Helmholtz H (1865) Die Lehre von den Tonempfindungen als physiologische Grundlage für die Theorie der Musik, 2nd edn. F. Vieweg und Sohn, Braunschweig
HeLmholtz H (1870) Die Lehre von den Tonempfindungen als physiologische Grundlage fur die Theorie der Musik, 3rd edn. F. Vieweg und Sohn, Braunschweig

Helmholtz H (1875) On the sensations of tone as a physiological basis for the theory of music translation of the third edition, 3rd edn. Longmans, Green, London

Helmholtz H (1877) Die Lehre von den Tonempfindungen als physiologische Grundlage fur die Theorie der Musik, 4th edn. F. Vieweg und Sohn, Braunschweig

Helmholtz H 1954 On the SENSATIONS OF tone as a Physiological basis FOR THE THEORY OF MUSIC. 2D ENGLISH ED., TRANSLATED, THOROUGHLY REVISED AND CORRECTED, RENDERED, CONFORMAL TO THE 4TH (AND LAST) German ed. of 1877, with numerous additional notes and a new additional appendix bringing down information to 1885 , and especially adapted to the use of music students. 4th ed: Dover Publications

Hensen V (1863) Zur Morphologie der Schneoke des Menschen und der Säugethiere. Z Wiss Zool 13:481-512

Hurst CH (1894) A new theory of hearing. Proc Liverpool Biol Soc 9:321-353

LEMPERT J (1938) Improvement of hearing in cases of otosclerosis: a new one stage surgical technique. Arch Otolaryngol Chicargo 24:42-97

Manni E, Petrosini L (1997) Domenico Cotugno, a pioneer in neurosciences. J Hist Neurosci 6:124-132

Manni E, Petrosini L (2010) Domenico Cotugno (1736-1822). J Neurol 257:152-153

Moos S, Steinbrügge H (1881) Ueber Nervenatrophie in der ersten Schneckenwindung. Zeitschrift Ohreilk 10:1-15

Mudry A, Mills M (2013) The early history of the cochlear implant: a retrospective. JAMA Otolaryngol Head Neck Surg 139:446-453

MülLER J (1826) Zur vergleichenden Physiologie des Gesichtssinns des Menchen und der Thiere. Zur vergleichenden Physiologie des Gesichtssinns des Menchen und der Thiere. Leipzig C Cnobloch:44-55

MülLER M (1996) The cochlear place-frequency map of the adult and developing Mongolian gerbil. Hear Res 94:148-156

NEFF WD (1984) Harold F. Schuknecht: beginnings in experimental research. Ann Otol Rhinol Laryngol Suppl 112:9-11

Онм G (1843) Ueber die Definition des Tones, nebst daran geknupfter Theorie der Sirene und ahnlicher tonbildener Vorrichtungen. Ann Phys 59:497-565

Perrault CDB (1680) Essais De Physique, Ou Recueil De Plusieurs Traitez touchant les choses naturelles. Paris Coignard:217-259

Plato (2017) translated By Jowett B. Timaeus. http:// WWWGUTENBERGORG/DIRS/ETEXT98/TMEUS11TXT2008

Robinson V (1941) Chronology of otology. BullHistMed 10:199-208

Schuknecht HF, NefF WD (1952) Hearing losses after apical lesions in the cochlea. Acta Otolaryngol 42:263-274

Siegel R 1970 Structure and function of the auditory organ. Galen ON SENSE RECEPTION: HIS DOCTRINES, OBSERVATIONS AND EXPERIMENTS ON VISION, HEARING, SMELL, TASTE, TOUCH AND PAIN , AND THEIR HISTORICAL SOURCES. BASAL: S. KARGER:127-39

Sigerist H (1961) A history of medicine: early Greek, Hindu and Persian medicine. Oxford University Press, New York

Smith KR, Wever EG (1949) The problem of stimulation deafness; the functional and histological effects of a high-frequency stimulus. J Exp Psychol 39:238-241

Stepanow E (1886) Zur Frag uber die Function der Cochlea. Monatsschr Ohrenheilk 20:116-124

Stepanow E (1888) Experimenteller Beitrag zur Frage ueber die Function der Schnecke. Monatschr Ohrenh 22:85-92

Tasaki I, Davis H, Legouix JP (1952) The space-time pattern of the cochlear microphonics (Guinea pig), as recorded by differential electrodes. J Acoust Soc Am 24:502-519 
vON BÉKÉSY G (1943) Uber die Resonanzkurve und die Abklingzeit der verschiedenen Stellen der Schneckentrennwand. Akust Z 8:66-76

WERNer H 1932 History of the Problem of DEAF-MUtism UNTIL the 17th cent. Jena [Germany]: Gustav Fischer

Wever E 1949 Theory of hearing. In: Langfeld H, ed. A Wiley publication in PSychology. New York: John Wiley \& Sons:5-7, 25 213,5

Wever EG, Bray CW (1930A) Auditory nerve Impluses. Science $71: 215$

WeVER EG, BRAY CW (1930B) Action currents in the auditory nerve in response to acoustical stimulation. Proc Natl Acad Sci U S A 16:344-350

WeVer E, Lawrence M (1949) The patterns of response in the cochlea. J Acoust Soc Am 21:127-134

Willis T 1672 De anima Brutorum. Oxonium: Davis

Willis T, Pordage S 1683 Two discourses Concerning the soul of BRUTES, WHICH IS THAT OF THE VITAL AND SENSITIVE OF MAN: THE FIRST IS
PHYSIOLOGICAL, SHEWING THE NATURE, PARTS, POWERS, AND AFFECTIONS OF THE SAME: THE OTHER IS PATHOLOGICAL, WHICH UNFOLDS THE DISEASES WHICH AFFECT IT AND ITS PRIMARY SEAT: TO WIT, THE BRAIN AND NERVOUS STOCK, AND THREATS OF THEIR CURES: WITH COPPER PLATES. London: Printed for Thomas Dring ..., Ch. Harper ..., And John LEIGH ...

Wilson C (1995) The invisible world: early modern philosophy and the invention of the microscope. Princeton, Princeton university press

ZwisLOCKI J (1946) Über die mechanische Klanganalyse des Ohrs. Cell Mol Life Sci 2:415-417

ZwisLOCKI J (1950) Theory of the acoustical action of the cochlea. J Acoust Soc Am 22:778-784

Publisher's Note Springer Nature remains neutral with regard to jurisdictional claims in published maps and institutional affiliations. 